Article

\title{
Didactics of Historical-Cultural Heritage QR Codes and the TPACK Model: An Analytic Revision of Three Classroom Experiences in Spanish Higher Education Contexts
}

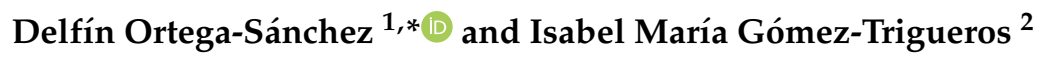 \\ 1 Department of Specific Didactics, Faculty of Education, University of Burgos, 09001 Burgos, Spain \\ 2 Department of General Didactics and Specific Didactics, Faculty of Education, University of Alicante, \\ 03690 Alicante, Spain; isabel.gomez@ua.es
}

Received: 12 April 2019; Accepted: 24 May 2019; Published: 29 May 2019

\begin{abstract}
This study aims to establish a first reference didactic and methodological framework for the operational and effective integration of Quick Response (QR) codes in the training of Social Sciences teachers in Primary Education, paying special attention to the integrated acquisition of social, civic, and digital competences in the framework TPACK (Technological Pedagogical Content Knowledge). With this purpose, it specifies the didactic potential of these new technological resources in the teaching-learning of the Social Sciences, its eventual integration in the design and implementation of teaching innovation projects for this educational stage, and its capacity for the acquisition of competence digital teaching in Primary Education teachers in initial training. In this sense, the work explores a selection of classroom experiences and research and innovation proposals, pioneers in the field of Social Sciences Didactics in Spain, with the aim of offering an approximation and status of the didactic treatment of History and, particularly, the historical-cultural heritage in the formation of Primary Education teachers.
\end{abstract}

Keywords: historical-cultural heritage; QR codes; teacher training

\section{Introduction}

The Information and Communication Technologies (ICT) have been one of the main revulsives for the formation of the already known information or knowledge society. Its evident influence in all areas of life reaches, in a decisive way, the educational field [1]. In this not-so-new reality, the integration of ICT in formal and informal education contexts offers numerous didactic possibilities in the design and implementation of teaching innovation projects for the improvement of the teaching and learning processes of the Social Sciences. The implementation of virtual classrooms such as MOOCs (Massive Open Online Courses) [2-4] or the use of emerging technologies such as mobile telephony or mobile electronic learning (Movile/M-learning) at school has supposed an "immersion of current society in the school context, considering it as a powerful educational tool due to its characteristics: portability, immediacy, connectivity, ubiquity and adaptability" [5] (p. 30).

\section{1. $Q R$ Codes}

In this context, the QR codes (Quick Response Code) break into the educational landscape as "information storage systems in the form of a matrix of points that encodes [wide and diverse] information [5] (p. 30), and where social and cultural contents find a preferential place [6]. The rapid response codes are "two-dimensional barcodes, identifiable by the three squares in the corners that 
allow the reader to detect the position of the code" [7] (p. 41). Its composition is that which follows (Figure 1).

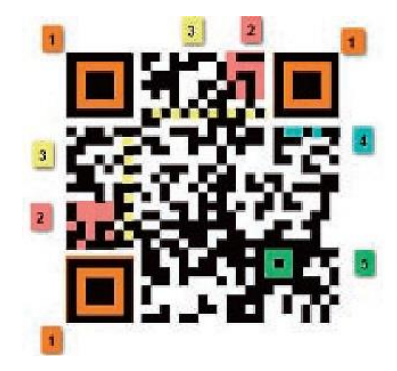

Zone 1. Position: the marks of the three corners allow the reader to locate the position of the code and start reading. It is convenient that around there is a white margin.

Zone 2. QR code version: zone 2 contains information about the version used to generate the code.

Zone 3. Alignment: the marks of zone 3 help the reader to correct the distortion generated by the perspective.

Zone 4. Format: zone 4 informs the reader QR of the data used, indicating if it is a VCARD, a URL, a text, an SMS ...

Zone 5. Synchronization: between the three position marks is zone 5, where the grid size of the matrix is indicated.

Figure 1. Functional description of a QR code [8] (p. 556).

According to the classification of Lens-Fitzgerald [9], the QR codes are in Level 0. Physical World Hyper Linking, the oldest of the applications of augmented reality (AR). This level is followed by three others: Level 1. Marker Based AR, Level 2. Markerless AR and Level 3. Augmented Vision.

In recent years, these codes have been present in the monumental urban heritage area as practical mediators of cultural and tourist information [10], reproducing or expanding it. However, its absence in historical and patrimonial education programs in initial training contexts of teachers is noteworthy.

Despite the positive educational value of these new ways of accessing information, on numerous occasions, driven by the volunteerism of the Primary and Secondary Education teachers, the integration of these codes or augmented reality strategies in the classroom of History and Heritage must be based on specific teacher training programs that allow analyzing its "didactic potentialities and to experiment with new methodologies capable of increasing the interest and involvement of students in their learning processes" [11] (p. 135). In this sense, the analysis should facilitate the problematization of social and cultural content, and the promotion of competency-based learning, through the proposal of methodologies in which the use of these codes will not result in the mere extension of textual or audiovisual information, but in the transforming generation of knowledge. Likewise, the integration of mobile technology in the classroom should guarantee the disciplinary, technological, and pedagogical merger-model TPACK-[12-15] in the teaching practice (Figure 2). 


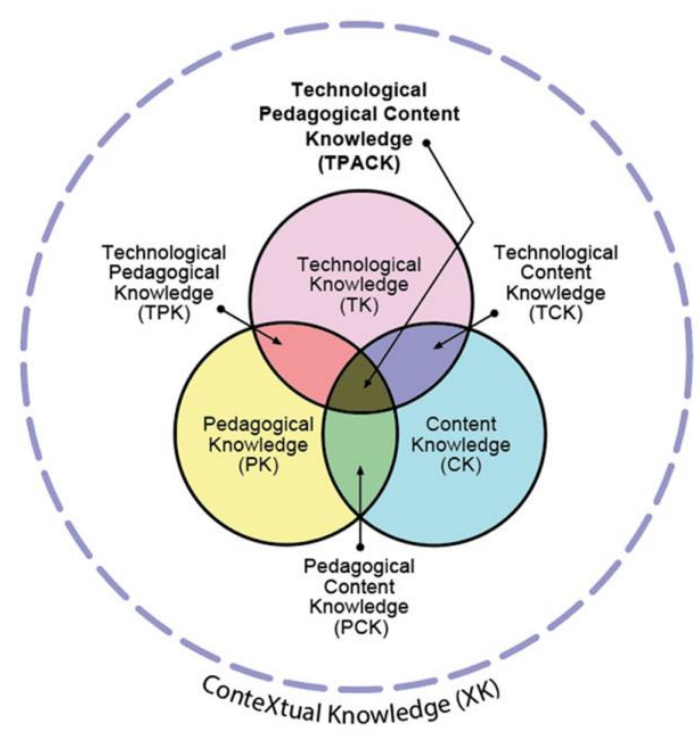

Figure 2. TPACK model [15].

\subsection{TPACK Model}

The relevance of this model, in relation to the integration of technologies in teacher training and in teaching-learning processes, is clear and can be seen in the many related publications [16-18] that have devoted ample literature to analyze it in the field of teacher training in Primary and Secondary education. In the same way, the context in which these interventions are carried out must be considered, as in many cases its success does not depend so much on the technological capabilities of the students that participate, nor on teachers, but on the degree of knowledge contextual (or XK) [15]. Thus, the XK would encompass a wide spectrum of elements that the teacher must control such as the educational policies that affect it or the regulations of the school, among other elements. It is, in short, a changing and essential knowledge to be able to carry out an adequate technological inclusion in the classrooms.

One of the problems detected in the use of the TPACK model is to measure the acquisition or not of the eight types of knowledge that it proposes in an individualized way. In this sense, several tools have been developed to evaluate the levels of achievement of the TPACK constructs without a resounding success because they have only been able to measure some of them. Such is the case of Graham et al. [19] that proposes a questionnaire able to check only four types of knowledge of the participants (TK -Technological Knowledge-, TCK -Technological Content Knowledge-, TPK -Technological Pedagogical Knowledge- and TPACK) or Lee \& Tsai [20] that use an original model to calculate the knowledge of teachers regarding the inclusion of the web in the classroom (TK, TPK, TCK and TPACK). Other studies are developed in specific contexts with very small samples that prevent generalizing the obtained values [21] or that consciously exclude some of the second-order elements of the TPACK model (TCK, PCK -Pedagogical Content Knowledge- and TPK) [16]. Also, and due to the novelty of the new construct incorporated by Mishra (2019) under the name of "contextual construct" (and identified with the acronym XK), the instruments so far made do not include the knowledge of the instructional environment in which ICTs are implemented. This knowledge must therefore have its place in the future evaluation questionnaires of the TPACK model since it is one of the eight structuring constructs of the model.

This review study approaches the implementation of QR codes in the teaching and learning of Social Sciences (until now, especially minority in didactic research results verifiable in Spain), in order to guide the implementation of future projects, experiences, and lines of research in Didactics of History and Historical-Cultural Heritage. To this end, we analyzed a first sample of didactic experiences with QR codes in initial training of teachers of Social Sciences of Primary Education from the TPACK model. 
Likewise, it is proposed to create an instrument that includes, individually, the level of acquisition of the eight constructs that make up the TPACK teaching and learning model, based on previous research.

\section{Materials and Methods}

The present study applies descriptive methodologies of documentary research [22] or research based on secondary sources, from the definition of two dimensions and two categories of analysis: Area 1. Dimension 1. QR codes and initial teacher training of Primary Education. Category 1. Methodological quality; Area 2. Dimension 2. Didactics of History and historical-cultural heritage. Category 2. Disciplinary, technological, pedagogical, and contextual consistency of the TPACK model [15]. These dimensions and categories were used as selection criteria for documentary material and as analysis operators.

The first dimension and the first category (area 1) seek to report on the adequacy of quality of the methodological procedure followed on the implementation of QR codes. This area of analysis is directly linked to the second dimension and the second category (area 2), aimed at describing the disciplinary, technological, pedagogical, and contextual consistency of the selected didactic interventions in the field of History and historical-cultural heritage. The results obtained served to design an instrument oriented to the evaluation of the TPACK model in digital education contexts in the initial teacher training.

The final sample consists of three classroom didactic experiences in the primary school teacher training contexts, aimed at teaching specific learning of History and heritage.

\section{Results}

\subsection{QR-Learning: Romanization in the Teaching of History}

This teaching innovation experience is based on a classroom practice aimed at students of the Primary Education Degree of the University of Alicante within the framework of a didactic of history course [23]. After the analysis of the previous ideas of the teachers in formation, the students had to design curricular materials on the process of romanization, by means of the creation of blogs linked to QR codes. Understanding this coding as part of what has come to be called "intelligent objects" with didactic intentionality, the codes were integrated into the research based on work with historical sources and the assumptions of meaningful learning in cooperative-collaborative methodologies, the favoring of consensual decisions, and the interactivity of the teacher in training with the different potentially usable digital materials and real social and cultural contexts.

From the comparative analysis of the answers obtained in the questionnaire after the realization of the practice and those obtained at the beginning of the activity, an overwhelming increase of conceptual, procedural, and attitudinal contents is revealed, passing "in some cases, to double or triple the students who acquired the concepts" [23] (p. 352), through the programmed integration of QR codes from the pedagogical assumptions of the TPACK model. On the other hand, the proposal values the importance of the context for the convenient incorporation of QR codes, although it is not mentioned if the real analysis of the different environments and the strengths and weaknesses that could arise in relation to them was considered.

\subsection{Development of Critical and Creative Thinking in Training Teachers of Arts: $Q R$ Codes}

The study is developed in the previous line of research [24]. In its methodological assumptions, the proposal incorporates $\mathrm{QR}$ codes to connect a large volume of digital materials with the aim of working digital competences, didactic-pedagogical competences, and disciplinary competences in the elaboration of curricular materials by the teachers in training; in short, the effective integration of the three areas of the TPACK model. The cooperative work and the degree of interactivity reached in the experience favored the development of critical and creative thinking around patrimonial historical-artistic contents, as well as competency-based learning. Likewise, and although it was not 
analyzed at the time, this proposal would allow the students to carry out a convergence with the specific context in which such interventions are implemented [15].

According to the results obtained, the design of QR codes, in charge of the teachers in training, incorporated social, civic, and emotional values in curricular materials on some of the main works of the History of Universal Art. In relation to the limitations of teacher implementation, researchers highlight the need for teacher training in the operational integration of mobile technology in the Social Sciences classroom of Primary Education. Similarly, and although not explicitly stated in the text, the need to develop the recognition of XK by trainee teachers is also detected.

\subsection{Emerging Technologies for the Teaching of Social Sciences. An Experience with the Use of Augmented Reality in the Initial Teacher Training}

Following a mixed methodology, the study [25] proposes the analysis of knowledge, opinions, and perceptions of teachers in initial training on the experimentation of emerging technologies, in particular, the Augmented Reality. Although our review focuses on the implementation of QR codes in the teaching-learning of History and heritage, we have considered, due to its representativeness in the field of teacher training, methodological quality and degree of integration of the TPACK model, this experience didactic developed in Level 1 of the classification of [9]: Augmented Reality of PC or desktop through the recognition of markers.

The didactic experience, realized with students of the Degrees in Early Childhood Education and Elementary Education at the University of Castilla-La Mancha enrolled in the subject Cultural Heritage, is aimed at the cooperative creation of objects of Augmented Reality for the teaching and learning of the closest cultural heritage. The objects created, mostly belonging to the Iberian archaeological heritage of the Provincial Museum of Albacete, were defended and evaluated through self-assessment of the work team, coevaluation and evaluation of the teacher responsible for the subject.

The answers given by the students who made the experience report a positive assessment of the Augmented Reality as a facilitator of historical, artistic, and heritage content. Researchers confirm the didactic potential of this tool, natural evolution of QR codes, and point out the need to work digital teaching skills. In this sense, they state, "it is not surprising that more than half of respondents indicate a need for initial training in this tool" [25] (p. 148). In relation to the three-dimensional fusion of the TPACK model, the study concludes affirming the need to integrate technological innovation in programmed didactic and disciplinary approaches. However, it is necessary to emphasize the importance of training in the contextual knowledge of trainee teachers for a better incorporation of disciplinary concepts, pedagogy, and technological tools [15] such as QR.

\section{Proposal of an Instrument for the Evaluation of Individual Constructs in Initial Teacher Training of Primary Education}

Although it is true that, as already indicated above, there is a huge literature referring to the instruments to analyze the elements of the TPACK model, it is also true that in all of them certain deficiencies are detected [16]. In this sense, and in view of the research studied, it is essential to have a tool that allows us to assess the different constructs that make up this model. For this reason, and based on the proposals already made by other authors $[13,16,19,21,26]$, we propose the following questionnaire that should be understood as an initial draft of the final tool. It is a project of 48 items with which to analyze, in a Likert scale of 1 (I totally disagree) to 5 (I totally agree), the level of acquisition of the eight constructs identified by the abbreviations CK, PK, TK, TCK, PCK, TPK, TPACK and XK, in an individualized way: 
Item 1 I have enough Social Sciences disciplinary knowledge to be able to teach the students of Childhood Education, and Primary and Secondary Education (depending on the level that you want to analyze).

Item 2 I am able to think about the content of Social Sciences as an expert on the subject.

Item 3 I am able to provide help to my students to understand the knowledge of the content I want to convey in various ways.

Item 4 I am able to develop a deeper understanding of the contents that I must convey in the classroom.

Item 5 I can use science tools such as (...) etc.

Item 6 I can adapt my teaching of Social Sciences to the knowledge of my students to make me understand.

Item 7 I am familiar with the comprehension processes of my students and with the misconceptions that they could have depending on the educational stage.

Item 8 I know the technologies that can help me progress in my training in disciplinary content.

Item 9 I have the technical skills to use software and hardware effectively in the classroom.

Item 10 I am able to easily learn software and hardware knowledge.

Item 11 I am able to solve my technical problems when I use technology (software and hardware).

Item 12 I can work with files, folders, create documents, save, move, and delete them on my computer or peripheral units.

Item 13 I can and I use Web resources such as pages, blogs, Wikis, QR codes, and similar for the teaching of Social Sciences.

Item 14 I can choose the technologies that improve the teaching of Social Sciences, depending on the level of education.

Item 15 I can and I choose technologies that improve the teaching and learning of Social Sciences in my classroom (Childhood Education, Primary Education, and/or Secondary Education).

Item 16 I think critically about how to use technology in my classroom (Childhood education, Primary Education, and/or Secondary Education).

Item 17 I can and I know how to adapt the use of the technologies to the different teaching activities in the classroom (Childhood education, Primary Education, and/or Secondary Education).

Item 18 I am able to select effective teaching approaches to guide students' thinking and learning of the contents. 
Item 19 I can help my students to reflect on their learning strategies.

Item 20 I can and I know how to select the effective teaching approaches and methodologies to guide students' thinking and their learning.

Item 21 I know how to organize and maintain classroom management.

Item 22 I am able to help my students monitor their own learning.

Item 23 I am able to guide my students to participate, effectively, during group work.

Item 24 I am able to guide my students to adopt appropriate learning strategies.

Item 25 I can stimulate the thinking of my students, creating tasks that are challenging for them.

Item 26 I can teach lessons that properly combine content, technologies, and active teaching methodologies (project work, problem-based learning / PBL, etc.).

Item 27 I can evaluate the learning process of students through various strategies.

Item 28 I know how to use a wide range of teaching methods in a class of Social Sciences, according to the educational level.

Item 29 I know how to evaluate the performance of students in the classroom.

Item 30 I am able to use specific technologies (multimedia resources, simulation) to facilitate the acquisition of social content.

Item 31 When designing curricular materials, I consider how technology can influence the approach to teaching that I will use in my classroom.

Item 32 I am able to provide my students with new learnings from the use of technologies.

Item 33 I can provide enough help to my students for group work, in a collaborative way, through the technologies.

Item 34 I can provide my students with the use of technology to build different forms of knowledge representation.

Item 35 I can use teaching-learning models that combine the contents of different areas, ICT and active methodologies, in my classroom (Childhood Education, Primary Education, and/or Secondary Education).

Item 36 I can teach lessons that adequately combine my knowledge of the discipline, technologies, and teaching approaches.

Item 37 I am able to select technologies in the classroom that improve what I teach, how I teach, and what students learn.

Item 38 I can use strategies that combine content, technologies, and teaching approaches that I learned throughout my training, in the classroom.

Item 39 I can provide leadership to help others coordinate the use of content, technologies, and teaching approaches in my classroom.

Item 40 I can provide help to other partners and I am able to coordinate the use of content, technologies, and teaching.

Item 41 I can provide leadership to help other colleagues coordinate the use of content, technologies, and teaching approaches in my school.

Item 42 I know the national regulations that affect me as a teacher (Childhood Education, Primary Education, and/or Secondary Education).

Item 43 I know the local regulations that affect me as a teacher (Childhood Education, Primary Education, and/or Secondary Education).

Item 44 I have sufficient knowledge about the legal documents that affect my school.

Item 45 I know the rules of coexistence of my school.

Item 46 I know the sociodemographic characteristics of my school.

Item 47 I know the existing services in the environment in which my school is located.

Item 48 I know the possibilities and resources that my school has.

Although this instrument has only been validated by experts from the University of Alicante and the University of Burgos and, although it has only been distributed among teachers working in two faculties of Education, an analysis has not yet been extracted of blunt reliability. Anyway, the questionnaire manages to differentiate all constructs of the TPACK model, collecting, through several items, different levels of each one of the eight elements that make it up.

\section{Discussion and Conclusions}

The curricular regulations of the different educational stages specify the need for transversal integration of ICT and the development of digital competence in the teaching-learning processes 
of the different areas of knowledge. Also, according to the guidelines of the Spanish Ministry of Education, the curricula of the Bachelor's degrees in Early Childhood and Primary Education prescribe, explicitly, the professional training of new professionals in the use of ICT, as well as its evaluation, and its social and transversal integration in the initial teacher training curriculum. However, we agree with Gómez-Gonzalvo in stating that "the lack of specific training of teachers in relation to the use of ICT in pedagogical contexts seems to be the main barrier to be overcome in the coming years" [5] (p. 32). Also, according to the results obtained in the questionnaire of perception passed to future teachers on technology and university teaching, "one of the great disadvantages that students see for the implementation of this type of innovative technologies [QR codes], is that in their Faculties and teachers are not yet sufficiently prepared to assume its implantation" [27] (p. 105).

In the same way, and in view of the revision carried out in the TPACK model, the importance of the new knowledge coined under the name of "contextual knowledge" and referenced with the acronym $\mathrm{XK}[15]$ is confirmed. According to the authors, there is a significant change recognizing the context as another domain of knowledge that trainee teachers must have to integrate ICT in teaching processes.

As the Gutiérrez Martín study demonstrates, "it does not seem that when preparing the initial teacher training plans, it has departed neither from the education law nor from the possible needs of the future society" [28] (p. 65). Despite the presence of ICT-specific subjects applied to education in the curricula of teachers in Primary Education, its independence from specific didactics is noteworthy. According to the results of Ortega [29] for the case of the Autonomous Community of Castilla y León, despite the lack of specific subjects designed for the integration of ICT and the development of competition digital in the teaching of Social Sciences, an effort can be observed for its incorporation in the objectives, contents, competences, and resources of the teaching guides of the Social Sciences subjects and its didactics. However, does this incorporation of ICT resources respond to an operational integration in the different curricula for the training of social science teachers?

The analyzed experiences respond, from the Didactics of History and Historical-Cultural Heritage, to one of the research lines proposed by Gómez-Gonzalvo, Atienza, and Mir [5] around the QR codes, based on the game and the need to contextualise learning outside the classroom. These didactic proposals, they affirm, "are able to integrate learning in real environments and in interaction with the cultural and architectural heritage of cities or semi-urban environments (gardens or parks)" (p. 33).

However, the implementation of QR codes, and its convergence with other applications of Augmented Reality in formative contexts of Primary Education teachers [30,31], should be oriented towards its instrumentalization as true didactic and methodological tools that are not substitutes for more traditional ones. In this line, the selected teaching innovation experiences are directed to the improvement of the teaching-learning process of the Social Sciences in the formative contexts of Primary Education teachers, to facilitate the effective operation of social and cultural contents in active methodologies, and promote the acquisition of cognitive abilities of higher order [32] and the social competency learning.

The use of QR codes as methodological tools transcends its reproductive information function to integrate into digital learning environments. Indeed, as evidenced by the experiences reviewed, the teacher is presented as a facilitator of a teaching-learning process in which the teacher in training must do something with social and historical information worked, solve a problem or analyze, create and evaluate content, thus distancing an informative reproduction or expansion from the use of a particular technological resource.

As we have had occasion to verify, this mobile technology favors cooperative-collaborative work, the acquisition of competency-based learning, and the development of communicative and instrumental skills. Likewise, the increase in students' motivation towards programmed content favors, at the same time, their participation, autonomy, and personal involvement in their own learning process. To these benefits, we must add the enormous potential they offer to develop contextualized knowledge of the closest space, enriching learning in Social Science content. 
Author Contributions: Conceptualization, D.O.-S. and I.M.G.-T.; methodology, D.O.-S.; formal analysis, D.O.-S.; investigation, D.O.-S. and I.M.G.-T.; resources, D.O.-S.; data curation, D.O.-S. and I.M.G.-T.; writing-original draft preparation, D.O.-S.; writing—review and editing, D.O.-S. and I.M.G.-T.

Funding: This research received no external funding.

Acknowledgments: This article is a strong overhauling and significant expansion of our study, published in Spanish, "Didáctica del patrimonio histórico-cultural y TICD códigos QR en la formación de maestros/as" [33]. This new study was approved by the Group of Teaching Innovation in Didactics of Social Sciences, Languages and Literatures in the initial training of teachers of Early Childhood Education and Primary Education (University of Burgos, Spain), and by the Research Group in Didactics of History and Social Sciences (DHISO/University of Burgos, Spain).

Conflicts of Interest: The authors declare no conflict of interest.

\section{References}

1. Marqués, P. Impacto de las TIC en la educación: Funciones y limitaciones. 3C TIC 2012, 2, 1-15.

2. Gómez-Trigueros, I.M.; Ortega-Sánchez, D. Los MOOC en la Didáctica de la Geografía: Aplicaciones en la formación inicial del profesorado de Primaria. In Nuevas Perspectivas Conceptuales y Metodológicas Para la Educación Geográfica; Martínez, R., Tonda, E., Eds.; Universidad de Córdoba: Córdoba, Spain, 2014; pp. 229-244.

3. Ortega-Sánchez, D.; Gómez-Trigueros, I.M. El MOOC como nueva estrategia/herramienta de enseñanza-aprendizaje en la Didáctica de la Geografía. In XIII Jornadas de Redes de Investigación en Docencia Universitaria: Nuevas Estrategias Organizativas y Metodológicas en la Formación Universitaria Para Responder a la Necesidad de Adaptación y Cambio; Tortosa, M.T., Álvarez, J.D., Pellín, N.C.M., Eds.; Universidad de Alicante-Instituto de Ciencias de la Educación: Alicante, Spain, 2015; pp. 44-54.

4. Ortega-Sánchez, D.; Gómez-Trigueros, I.M.; Moreno, J.R. Competencia digital, digitalización de la formación y MOOC para maestros/as de Geografía de Educación Primaria. In La Investigación e Innovación en la enseñanza de la Geografía; Sebastiá, R., Tonda, E., Eds.; Universidad de Alicante: Alicante, Spain, 2016; pp. 363-373.

5. Gómez-Gonzalvo, F.; Atienza, R.; Mir, M. Revisión bibliográfica sobre usos pedagógicos de los códigos QR. @tic 2015, 15, 29-37.

6. Crompton, H.; LaFrance, J.; van't Hooft, M. QR Codes 101. Learn. Lead. Technol. 2012, 39, 22-25.

7. Meneses, L. Códigos QR: Museografía urbana para la puesta en valor del Patrimonio Cultural. Eltopo Revista de Sociología Cultural y Urbana 2014, 3, 32-55.

8. Silva, J.M. Aplicaciones de los códigos QR y la realidad aumentada en la enseñanza de las Ciencias Sociales. In Medios de Comunicación y Pensamiento Crítico: Nuevas Formas de Interacción Social; Díaz, J.J., Santisteban, A., Cascajero, A., Eds.; Universidad de Alcalá-Asociación Universitaria del Profesorado de Didáctica de las Ciencias Sociales: Alcalá, Spain, 2013; pp. 553-573.

9. Lens-Fitgerald, M. Sprxmobile, Augmented Reality Hype Cycle. Available online: http://www.sprxmobile. com/the-augmented-reality-hype-cycle (accessed on 3 April 2018).

10. Grevtsova, I. El patrimonio urbano al alcance de la mano: Arquitectura, urbanismo y Apps. Her. Mus. 2013, $5,36-43$.

11. Estebanell, M.; Ferrés, J.; Cornellas, P.; Codina, D. Realidad aumentada y códigos QR en educación. In Tendencias Emergentes en Educación con TIC; Hernández, J., Pennesi, M., Sobrino, D., Vázquez, A., Eds.; Espiral: Barcelona, Spain, 2012; pp. 135-157.

12. Cózar, R.; Zagalaz, J.; Sáez, J.M. Creando contenidos curriculares digitales de Ciencias Sociales para Educación Primaria. Una experiencia TPACK para futuros docentes. Educatio Siglo XXI 2015, 22, 147-168. [CrossRef]

13. Gómez-Trigueros, I.M. Proyecto a partir del modelo TPACK para desarrollar el aprendizaje de la Geografía en los estudios de grado de Educación Primaria. Ph.D. Thesis, University of Alicante, Alicante, Spain, 2015.

14. Mishra, P.; Koehler, M.J. Technological Pedagogical Content Knowledge: A new framework for teacher knowledge. Teach. Coll. Rec. 2006, 108, 1017-1054. [CrossRef]

15. Mishra, P. Considering Contextual Knowledge: The TPACK Diagram Gets an Upgrade. J. Dig. Learn. Teach. Educ. 2019. [CrossRef]

16. Chai, Ch.S.; Koh, J.H.; Tsai, Ch. Exploring the factor structure of the constructs of technological, pedagogical, content knowledge (TPACK). Asia Pac. Educ. Res. 2011, 20, 595-603. 
17. Harris, J.; Mishra, P.; Koehler, M. Teachers' technological pedagogical content knowledge and learning activity types: Curriculum-based technology integration reframed. J. Res. Technol. Educ. 2009, 41, 393-416. [CrossRef]

18. Jang, S.J.; Chen, K.C. From PCK to TPACK: Developing a transformative model for preservice science seachers. J. Sci. Educ. Technol. 2010, 19, 553-564. [CrossRef]

19. Graham, R.C.; Burgoyne, N.; Cantrell, P.; Smith, L.; St. Clair, L.; Harris, R. Measuring the TPCK confidence of inservice science teachers. TechTrends 2009, 53, 70-79.

20. Lee, M.; Tsai, C. Exploring teachers' perceived self efficacy and technological pedagogical content knowledge with respect to educational use of the world wide web. Instructional Science: An International Journal of the Learning Sciences 2010, 38, 1-21. [CrossRef]

21. Schmidt, D.A.; Baran, E.; Thompson, A.D.; Mishra, P.; Koehler, M.J.; Shin, T.S. Technological Pedagogical Content Knowledge (TPCK): The development and validation of an assessment instrument for preservice teachers. J. Res. Technol. Educ. 2009, 42, 27. [CrossRef]

22. Barbosa, J.W.; Barbosa, J.C.; Rodríguez, M. Revisión y análisis documental para estado del arte: Una propuesta metodológica desde el contexto de la sistematización de experiencias educativas. Investig. Bibliotecol. 2013, $27,83-105$.

23. Moreno, J.R.; Vera, M.I.; Seva, F.; Quiñonero, F.; Pérez, T.D.; del Soriano, M.C. QR-Learning: La romanización en la enseñanza de Historia. In XIII Jornadas de Redes de Investigación en Docencia Universitaria: Nuevas estrategias Organizativas y Metodológicas en la Formación Universitaria Para Responder a la Necesidad de Adaptación y Cambio; Tortosa, M.T., Álvarez, J.D., Pellín, N., Eds.; Universidad de Alicante-Instituto de Ciencias de la Educación: Alicante, Spain, 2015; pp. 340-352.

24. Moreno, J.R.; López, I.; Vera, M.I. Development of Creative and Educational thinking in Arts training teachers: QR Codes. Sylwan J. 2014, 158, 185-200.

25. Cózar, R.; del Valle Moya, M.; Hernández, J.A.; Hernández, J.R. Tecnologías emergentes para la enseñanza de las Ciencias Sociales. Una experiencia con el uso de Realidad Aumentada en la formación inicial de maestros. Dig. Educ. Rev. 2015, 27, 138-153.

26. Archambault, L.M.; Barnett, J.H. Revisiting technological pedagogical content knowledge: Exploring the TPCK framework. Comput. Educ. 2010, 55, 1656-1662. [CrossRef]

27. Román-Graván, P. Diseño, elaboración y puesta en práctica de un observatorio virtual de códigos QR. @tic 2012, 9, 96-107. [CrossRef]

28. Gutiérrez, A. Formación del profesorado para la alfabetización múltiple. In Alfabetización Digital y Competencias Informacionales; Area, M., Gutiérrez, A., Martín, V.F., Eds.; Ariel: Barcelona, Spain; Fundación Telefónica: Madrid, Spain, 2012; pp. 43-98.

29. Ortega-Sánchez, D. La enseñanza de las Ciencias Sociales, las TIC y el Tratamiento de la Información y Competencia Digital (TICD) en el Grado de Maestro/a de Educación Primaria de las Universidades de Castilla y León. Enseñanza de las Ciencias Sociales 2015, 14, 121-134.

30. Cózar, R.; Guerrero, O. La Realidad Aumentada en la enseñanza/aprendizaje de las Ciencias Sociales. In Investigación e innovación en formación del profesorado; Maquilón, J.J., Orcajada, N., Eds.; Universidad de Murcia: Murcia, Spain, 2014; pp. 433-443.

31. Cózar, R.; Guerrero, O. La realidad aumentada como recurso para la enseñanza de la Historia e Historia del Arte en Educación Primaria. In Competencia Digital y Tratamiento de la Información. Aprender en el Siglo XXI; Callejas, A.I., Salido, J.V., Jerez, O., Eds.; Universidad de Castilla-La Mancha: Cuenca, Spain, 2016; pp. $29-46$.

32. Anderson, L.W.; Krathwohl, D. A Taxonomy for Learning, Teaching and Assessing: A Revisión of Bloom's Taxonomy of Educational Objectives; Longman: New York, NY, USA, 2001.

33. Ortega-Sánchez, D.; Pérez-González, C. Didáctica del patrimonio histórico-cultural y TICD códigos QR en la formación de maestros/as. In XIV Jornadas de Redes de Investigación en Docencia Universitaria: Investigación, Innovación y Enseñanza Universitaria: Enfoques Pluridisciplinares; Tortosa, M.T., Grau, S., Álvarez, J., Eds.; Universidad de Alicante-Instituto de Ciencias de la Educación: Alicante, Spain, 2016; pp. 557-568.

(C) 2019 by the author. Licensee MDPI, Basel, Switzerland. This article is an open access article distributed under the terms and conditions of the Creative Commons Attribution (CC BY) license (http://creativecommons.org/licenses/by/4.0/). 